\title{
PUBLIC SERVICE INNOVATION FOR PUBLIC TRANSPORTATION TO DISABILITIES BY DIFA CITY TOUR, YOGYAKAR CITY
}

\author{
Muhammad Iqbal ${ }^{1,}$, , Auliya Tri Anggraini2 \\ ${ }^{1}$ Government Affairs and Administration, Universitas Muhammadiyah Yogyakarta, Indonesia \\ 2 Faculty of Social and Political Science, Universitas Gadjah Mada, Indonesia
}

ABSTRACT - This research was conducted with the aim of analyzing Public Service Innovations in the Field of Transportation for Persons with Disabilities by Difa City Tour City of Yogyakarta, Public Service Standards for Disability Services by Difa City Tour, obstacles in conducting Public Service Innovations in the Field of Disability Transportation by Difa City Yogyakarta City Tour. This study uses qualitative research techniques with interview methods and documentation. The results showed that the innovation of public services for persons with disabilities was in the form of threewheeled transportation facilities specifically designed according to the needs of disabilities with a level of friendliness and comfort. Besides, the system is made in a service procedure that is technology-based or digital-based, which provides shuttle services and mobilizes persons with disabilities in a system that created while creating jobs for people with disabilities.
ARTICLE HISTORY

Received: 25-09-2019

Accepted: 03-12-2019

\section{KEYWORDS}

Service Innovation; public service; public transportation; diffable

\section{INTRODUCTION}

Pursuant to Law Number 4 of 1997 concerning Persons with Disabilities Article 1 point (1) states that a person with a disability is any person who has a physical and/or mental disability, which can interfere or constitute an obstacle and an obstacle for him to carry out his activities properly, which consists from; people with physical disabilities; people with mental disabilities; people with physical and mental disabilities. UN data reveals that $10 \%$ of the total world population, or around 650 million, are people with disabilities (Mackelprang \& Salsgiver, 2016). A report submitted by the World Bank shows that about $20 \%$ of people with disabilities worldwide come from economically weak classes (Mackelprang \& Salsgiver, 2016). As for the number of disabilities in Indonesia based on data from the Central Statistics Agency (BPS) of the Republic of Indonesia in 2011, there were 9,046,000 people.

Meanwhile, the number of disabilities in the Special Region of Yogyakarta (DIY) increased after the 2006 earthquake struck. According to data from the DIY Social Service in 2011, from five districts/cities in Yogyakarta, Kulonprogo Regency amounted to 5914, Bantul Regency 8367, Gunungkidul Regency, 9905 Sleman Regency 8256 and Yogyakarta City 3353. From data based on the DIY Social Service, the number of disabilities in DIY in 2011 was 35,264 people.

Where persons with disabilities are also citizens of the Republic of Indonesia, which in the 1945 Constitution is guaranteed to have the same position, rights, obligations, and roles as other citizens, the 1945 Constitution stipulates that "Everyone has the right to get individual facilities and treatment to obtain equal opportunities and benefits in order to achieve equality and justice. However, public services for persons with disabilities can be said to be less fulfilled. Facts show that there are still many conditions in the field in the form of accessibility barriers in social services in the way of architectural and procedural obstacles. This makes people with disabilities lose their rights to get equal or excellent service. In terms of accessibility, the availability of friendly facilities and infrastructure in the field of transportation for disabilities is currently still very limited in Indonesia in general and Yogyakarta in particular (Dewi, 2013: 15).

Although there have been efforts and efforts in providing exceptional services carried out by the government for persons with disabilities in the field of public transport facilities, it can be said that most still do not meet the minimum standard of an accessibility concept that is easily accessible and friendly for persons with disabilities, where the provision of facilities that are accessible to services in public transportation is essential for people with disabilities in carrying out activities and daily activities, when viewed from the concept of Good Governance where good governance can be interpreted as a reference for the process and structure of political and socio-economic relations. Efforts to create good governance can only be made if there is a balance between the roles of the three pillars, namely private and community governance. In connection with the concept of good governance that civil society is allowed to express interests in service management, then the government or service providers must make the public interest the main criteria in service delivery.

In the city of Yogyakarta there is an innovative public service in the field of transportation for people with disabilities. Where public service innovation is a breakthrough type of assistance either from a creative or modified idea or idea that can provide benefits to the community both directly and indirectly. The change in transportation was named "Difa City Tour." 
Another reason for the establishment of a motorcycle taxi service disability, as reported by the Jogja Tribune, was the first that departed from the disability needs second, because people with disabilities in the city of Yogyakarta are still difficult to access public transport services that exist because of the lack of accessibility and friendly for people with disabilities to carry out daily activities. With the Difa City Tour or can be called a motorcycle taxi can help and make it easier for people with disabilities to access transportation. Not only that, but the innovation is unique, where all involving persons with disabilities, especially for transportation means, are people with special needs.

\section{METHODOLOGY}

The methods section describes actions to be taken to investigate a research problem and the rationale for the application of specific procedures or techniques used to identify, select, process, and analyze information applied to understanding the problem, thereby, allowing the reader to critically evaluate a study's overall validity and reliability. The methodology section of a research paper answers two main questions: How was the data collected or generated? And, how was it analyzed? The writing should be direct and precise and always written in the past tense.

\section{RESULTS}

\section{The innovation of public services for disabilities}

In terms of excellence in the field of transportation by the DFA city tour for persons with disabilities when compared to public transportation in Yogyakarta, it is undoubtedly superior where Difa City Tour itself has its uniqueness starting from the idea in the innovation of motorcycle taxi drivers, drivers, passengers, all with disabilities. This service is also more friendly to people with disabilities because the accessibility and procedural services that receive shuttle services make it easier for people with disabilities.

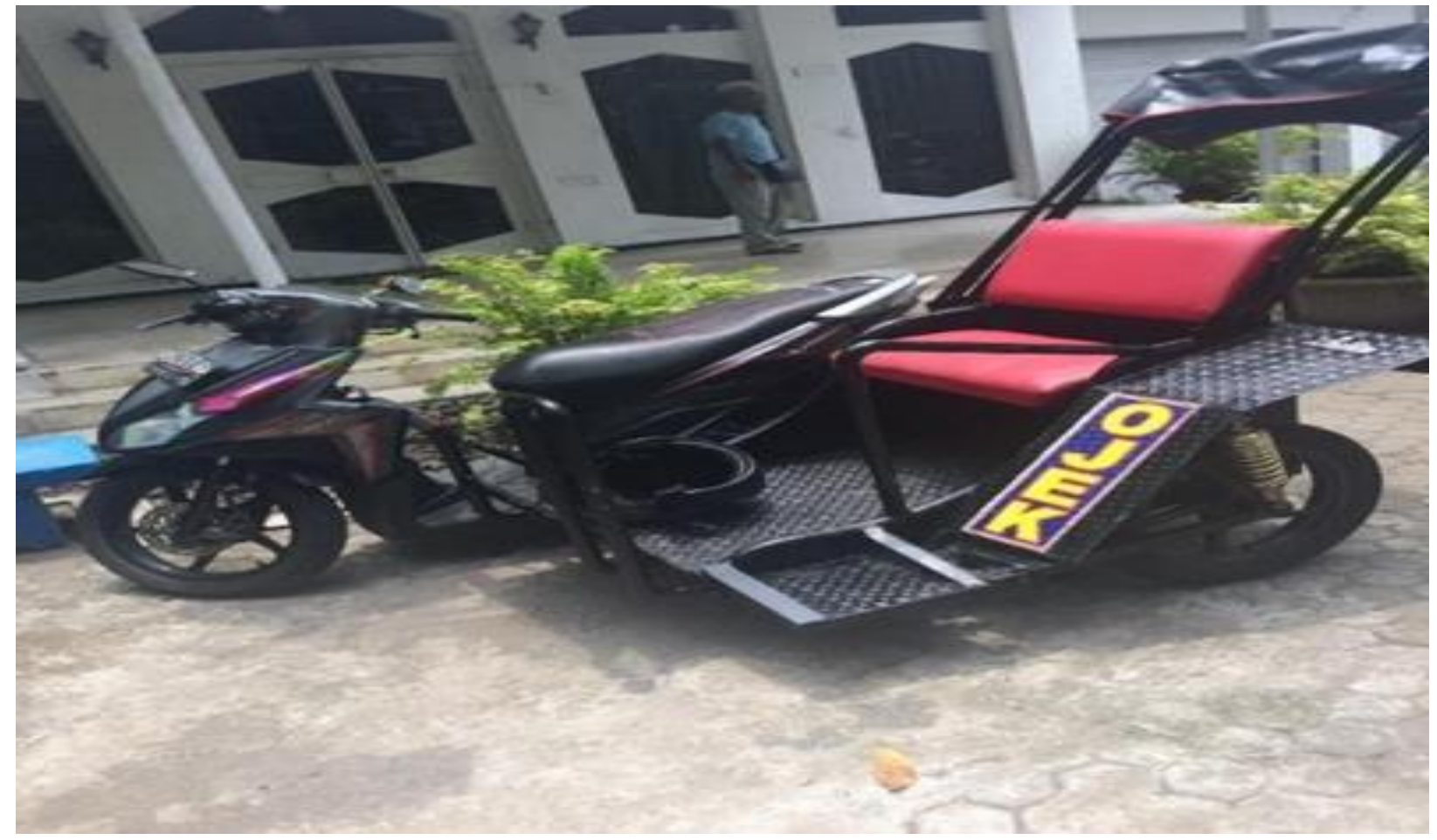

Figure 1: Transportation Innovation by Difa City Tour

\section{Suitability}

The innovation was made based on the suitability of disability needs, although in general, it has accommodated the needs and desires of persons with disabilities. For example, Difa city tour designed a modified motorbike by providing facilities for both wheelchair users and disabled people who do not use wheelchairs so that all people with disabilities can use transportation innovations. At the same time, creating jobs by helping people with disabilities who want to work to make a living.

\section{Hassle-Free}

The complexity is found in the process of making a Difa motorcycle taxi design wherein the process of making a motorcycle taxi must be following the character of the disability. Because Difa motorcycle taxi drivers who accommodate people with disabilities certainly have different disability groups by people with disabilities so that in designing the motorcycle taxi motorbike, the character is modified according to disability needs. 


\section{Possible Try}

Innovation can only be accepted if it has been tested and proven the old. An innovation product must pass the "public test" phase, determined that this innovation provides benefits for disabilities in Yogyakarta, although the service innovation program conducted by Difa City Tour has not been implemented long enough. Still, the response from the positive community has been widely received by the community both disability and other general public who are outside the city of Yogyakarta who are asking to be able to develop this transportation service innovation to other cities, which indicates that there has been a point of success with the presence of the innovation addition or called the ojek motorcycle taxi received appreciation from the city government of Yogyakarta where the innovation is the only one in the world.

\section{Service Procedure}

The services provided in accessing transportation/motorcycle taxi are all based on technology or digital. Service procedures in obtaining services can directly contact via telephone or SMS as well as the application Difa bike to make the shuttle to the Difa Tour City. In the method of service procedures using the DifaBike application, it is not yet optimal in using the DifaBike application service because the public prefers via telephone / SMS. In organizing public services. As the DifaBike application made a complaint service to see how excellent service provided to persons with disabilities by the city tour Difa there is no complaint service available to service users.

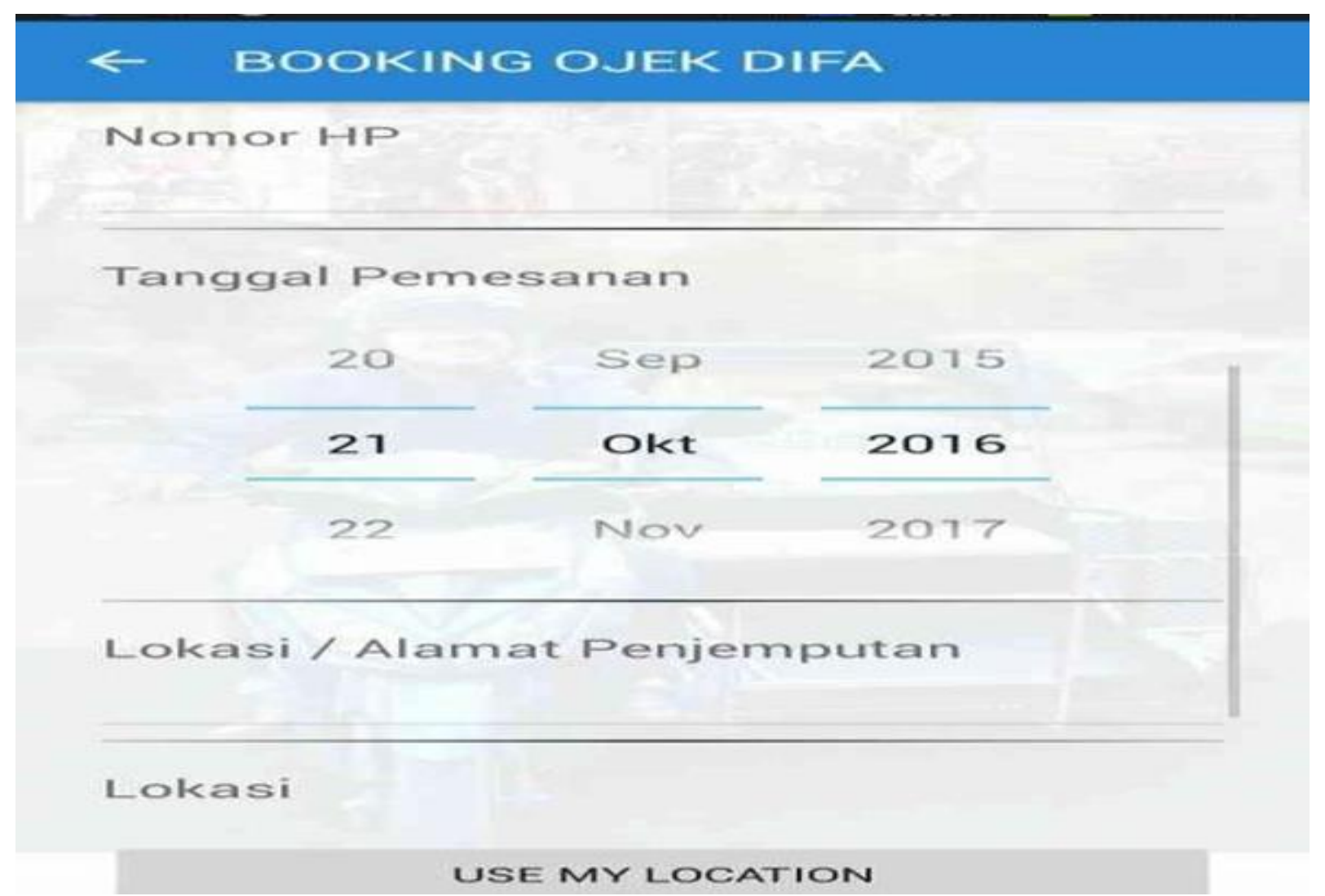

Figure 2: Difa Bike Service Procedure

\section{Cost}

The Ojek Difa motorcycle service has provided explicit details of the cost of service as well as for making outlets and banners installed at Difa City Tour offices. Like the shuttle fee Rp.20000 for $5 \mathrm{~km}+2500$ for the next Km. In terms of fees, Service costs are one of the standard public services. Service costs, including the details, must be determined consistently so as not to cause discrimination because this can lead to distrust of service recipients to service providers. The cost of this service must be precise on each service to be provided to the community so that it does not cause anxiety, especially to parties or the public.

\section{Facilities and infrastructure}

Facilities modified by the Difa city tour are motorcycles with three wheels. Facilities used are motorcycles with three wheels that are set or modified according to disability needs (see Figure 3 and Figure 4). In terms of modified motor facilities, there are two types, the first specifically for persons with disabilities who use wheelchairs. Second for people who do not use wheelchairs such as the blind etc. Then in terms of infrastructure, Difa City Tour has an office located on Harjowinatan Puro Pakualaman street as a place of interaction between the DIFA drivers and customers. 


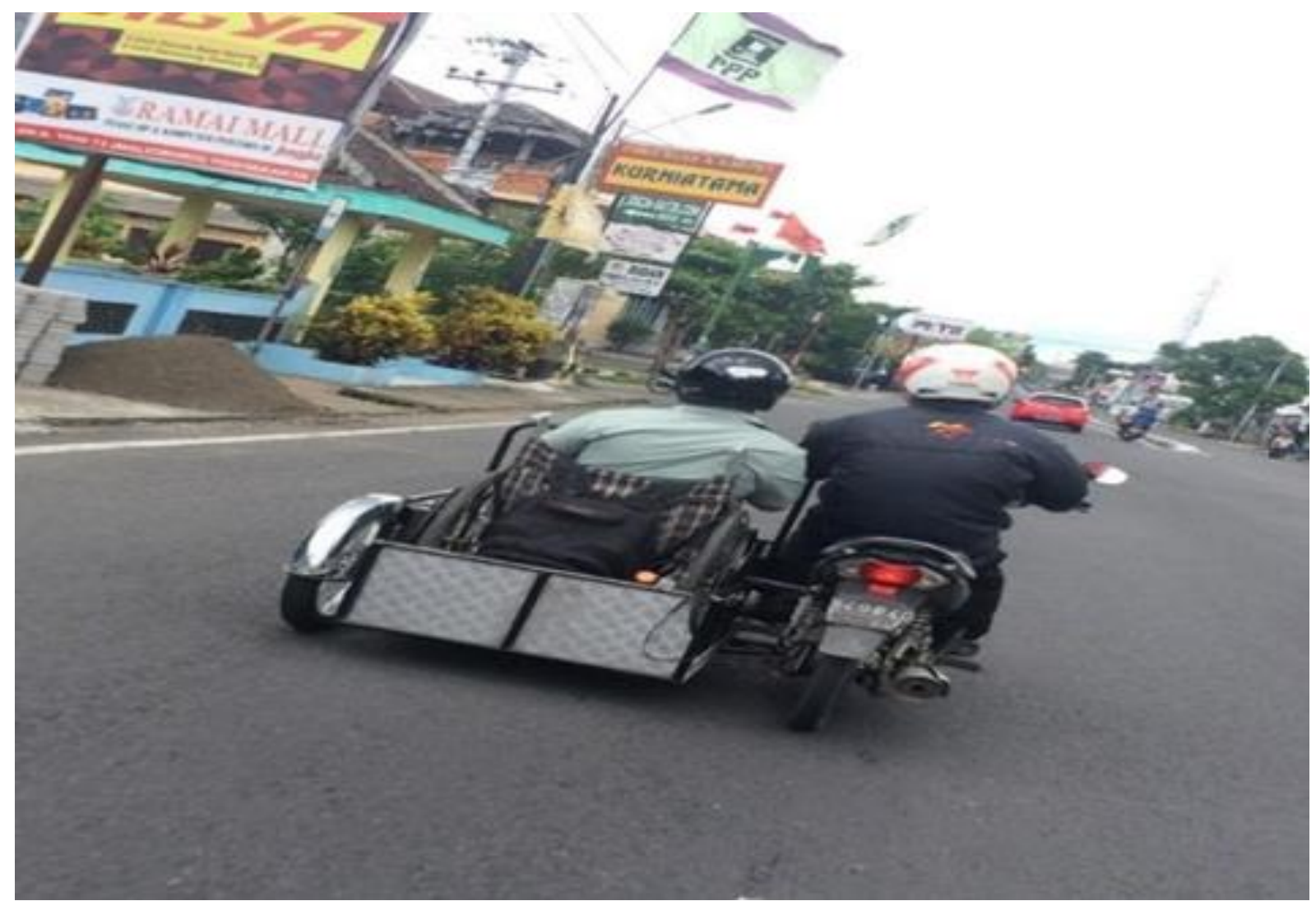

Figure 3: Difa motorcycle taxi facilities for wheelchair users by Difa City Tour

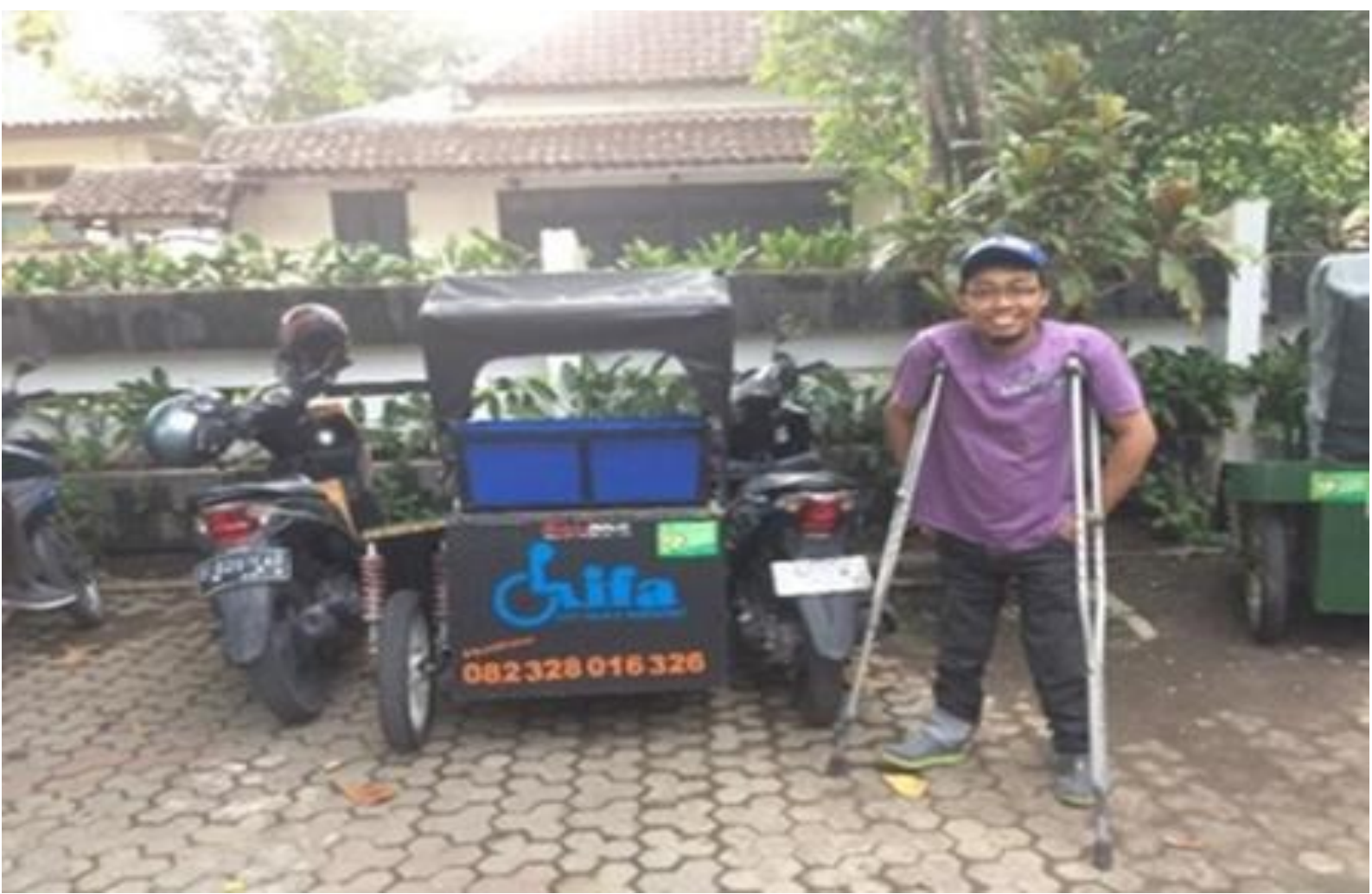

Figure 4: Non-Wheelchair Motorcycle taxi

\section{Competency of Giving Officers}

Difa City Tour service has previously conducted an employee trying in which the employee trying is the initial stage undertaken at the city tour to the job applicants who register. In the recruitment process that is done by looking at the competency in the form of skill drivers by employee applicants because skill drivers are prioritized, then an understanding of the Yogyakarta city road route where the service is directly related to going down to the highway. And provide 
knowledge about the technology used to support the application system in use. So that the competency of employees in service providers offered by Difa City Tour has implemented employee competencies.

\section{Ease of Access}

For the affordability of places or locations for passengers who want to use a motorcycle taxi, especially for the city of Yogyakarta is not optimal to reach areas where the city tour has only 20 fleets so that not too many fleets are spread in the city of Yogyakarta, but especially for people with disabilities most order by telephone for the passenger shuttle service. So, it can be concluded that the standard of service in the ease of access by the Difa city tour there are still constraints on the location and fleet that are not yet widely available by the reach of people with disabilities.

\section{Security}

Guaranteed security and safety of services is a form of commitment to provide a sense of security, free from danger, risk, and doubt. Especially in the innovation of public services in the field of transportation for persons with disabilities who have a high chance in public services to customers or users of Difa City Tour services. Difa city tour from within the service standard has met and complied with the rules following the terms and conditions of the regulations made by the Yogyakarta City Transportation Agency in modifying the three-wheeled motorbike. Even though the administrative matters regarding the Transportation Service Business License for motorcycle taxis are still in the process of finishing. Whereas regarding SIM, all drivers already have SIM D in terms of legal certainty.

\section{Short Term Budget (Capital) \& planning}

Innovation systems that are carried out often occur obstacles in the implementation process that requires costs to realize the implementation of the community. From internal factors, there are constraints regarding the budget where Difa City Tour for the budget in modifying the motorcycle taxi costs 3.5-4 million while in increasing the fleet if the private driver does not have a motorbike, the city tour budget allocates for vehicle facility costs ranging from IDR 11 million to IDR 13 million.

\section{There are no rewards or incentives}

This transportation innovation gets appreciation from the mayor of Yogyakarta, where the government gives gratitude to the Difa city tour in making an update in the field of transportation for the disabled because the motorcycle taxi is in line with the vision goals of the city of Yogyakarta. One of the visions of Yogyakarta city is the realization of the city of Yogyakarta as an inclusive city. However, external factors such as support and participation of the government with the innovation of transportation facilities for persons with disabilities in the city of Yogyakarta, there has not been any real form until now. Both in the form of finance, facilities provided, or the ease of cooperation between related agencies where the role and support of the government.

\section{CONCLUSION}

The innovations made by Difa City Tour are innovative, not just innovating, but in the change, they have advantages, benefits, and conformity that are adjusted to the needs of disability. Public Service Standards in the Field of Transportation for Disability by Difa Tour City has led to civil service standards in accordance with Decree of the Minister of Manpower No. 6 of 2003 concerning guidelines for the delivery of public services ranging from service procedures, cost details, facilities and infrastructure, competency of service providers, facilities access, security. Constraints in Innovating Public Services in the Field of Transportation for Disabilities by Difa Tour City of Yogyakarta, there are two factors, namely internal and external factors. Both from the budget and support from the government in innovating services in the field of transport for disability.

\section{REFERENCES}

Caccese, J. B., Buckley, T. A., Tierney, R. T., Arbogast, K. B., Rose, W. C., Glutting, J. J., \& Kaminski, T. W. (2018). Head and neck size and neck strength predict linear and rotational acceleration during purposeful soccer heading. Sports Biomechanics, 17(4), 462-476.

Huang, X., Sun, J., \& Sun, J. (2018). A car-following model considering asymmetric driving behavior based on long short-term memory neural networks. Transportation Research Part C: Emerging Technologies, 95(February), 346-362.

James, S. L., Abate, D., Abate, K. H., Abay, S. M., Abbafati, C., Abbasi, N., Abbastabar, H., Abd-Allah, F., Abdela, J., Abdelalim, A., Abdollahpour, I., Abdulkader, R. S., Abebe, Z., Abera, S. F., Abil, O. Z., Abraha, H. N., Abu-Raddad, L. J., Abu-Rmeileh, N. M. E., Accrombessi, M. M. K., ... Murray, C. J. L. (2018). Global, regional, and national incidence, prevalence, and years lived with disability for 354 diseases and injuries for 195 countries and territories, 1990-2017: a systematic analysis for the Global Burden of Disease Study 2017. The Lancet, 392(10159), 1789-1858.

Tan, H., Qin, L., Jiang, Z. Albury, David. 2003. Inovasi di Sektor Publik. Jakarta: PT Elex Media Komputindo

Arifin Tahir. 2014. Kebijakan Publik dan Transparansi Penyelenggaraan Pemerintah Daerah. Alfabeta. Bandung.

Barata, Atep. 2004. Dasar- dasar Pelayanan Prima. Jakarta: Elex Media. Komputindo

Didi Trasidi. 2012. Kendala Umum yang Dihadapi Penyandang Disabilitas dalam Mengakses Layanan Publik. JMS1_Anakku. Volume 10. Nomor 2. Universitas Pendidikan Indonesia Erawati Dayang. 2012. Inovasi Pelayanan Publik Di Kecamatan Sungai Kunjang Kota Samarinda. Jurnal Ilmu Pemerintahan, Vol 3. No 2

Faelan, Riza. 2013. Studi Tentang Kualitas Pelayanan Publik Pada Badan Perpustakaan Provinsi Kalimantan Timur. Jurnal administrasi 
negara, volume 1, nomor 1, 2013: 56-69

Gadis Arivia dkk, 2012. Mencari Ruang Untuk Difabel. Jakarta: YJP.

Harjanto, Sri., 2004. Dari Sistem Inovasi Nasional ke ABG: Catatan Kebijakan Iptek Nasional.Jurnal Inovasi, Vol. 2/XVI/November 2004

Kasmir. 2006. Manajemen Perbankan. Jakarta: PT. Raja Grafindo Persada.

Keputusan Menteri Pendayagunaan Aparatur Negara Nomor 63 Tahun 2003Tentang Pedoman Penyelenggaraan Pelayanan.

Kurniawan, Agung. 2005. Transformasi Pelayanan Publik. Yogyakarta: Pembaruan

Lembar Negara RI Tahun 1997, Nomor 9. Sekretariat Negara. Jakarta.

Lubis Arif Hendra. 2008. Kajian Aksesbilitas Difabel Pada Ruang Publik Kota Studi Kasus: Lapangan Merdeka. Universitas Sumatra Medan

Mackelprang, R. W., Salsgiver, R. O., \& Salsgiver, R. (2016). Disability: A diversity model approach in human service practice. Oxford University Press.

Moenir, H.A.S. 1992. Manajemen Pelayanan Umum Di Indonesia. PT Bumi Aksara. Jakarta

Moleong, Lexy. 2004. Metode Penelitian Kualitatif. Bandung: PT Remaja Rosda Karya

Provinsi Daerah Istimewa Yogyakarta. 2012. Peraturan Daerah Nomor 4 Tahun 2012 tentang Perlindungan dan Pemenuhan Hak-Hak Kaum Disabilitas. Lembaran Daerah Istimewa Yogyakarta Nomor 4. Sekretariat Daerah. Yogyakarta

Rahayu Sugi, Dewi Utami. 2013 Pelayanan publik bagi pemenuhan hak-hak disabilitas Di kota Yogyakarta. Jurnal SOCIA. Vol 1. No 1

Repindowaty, Rahayu. 2015. Perlindungan Hukum Terhadap Penyandang Disabilitas. Jurnal Inovatif. Vol VIII. No 1.

Republik Indonesia. 1997. Undang - Undang Nomor 4 Tahun 1997 tentang Penyandang Cacat.

Republik Indonesia. 2009 Undang - Undang Nomor 25 Tahun 2009 tentang Pelayanan Publik. Lembar Negara RI Tahun 1997, Nomor 107. Sekretariat Negara. Jakarta.

Sinambela Poltak Lijan dkk. 2014. Reformasi Pelayanan Publik. PT Bumi Aksara. Jakarta

Winarsih, Septi Atik \& Ratminto. 2005. Manajemen Pelayanan. Pustaka Pelajar. Jogja., Wu, Y., \& Ran, B. (2018). A hybrid deep learning based traffic flow prediction method and its understanding. Transportation Research Part C: Emerging Technologies, 90(January), 166-180.

Taylor, K., Post, A., Hoshizaki, T. B., \& Gilchrist, M. D. (2019). The effect of a novel impact management strategy on maximum principal strain for reconstructions of American football concussive events. Proceedings of the Institution of Mechanical Engineers, Part P: Journal of Sports Engineering and Technology, 233(4), 503-513. 